\title{
PAUL ARISTE AND THE VEPS FOLKLORE
}

\section{Kristi Salve}

\begin{abstract}
The Vepsian folklore and language remained in the periphery of Paul Ariste's research subjects. Most of his fieldwork materials were destroyed in the 1965 fire, a small part of the collection is preserved in the Literary Museum (mostly folk songs, but also folk tales). P. Ariste has also published some of the Vepsian folk tales he collected ("Vepsa muinasjutte" [The Folk Tales of the Veps], Tallinn 1964). Paul Ariste's greatest contribution to the study of the Veps, both folklore and language, was his work at educating new generations of researchers of the Vepsian folklore.
\end{abstract}

Keywords: Paul Ariste, Vepsian folklore, folk songs, folk tales, Roman folklore.

\section{Introduction: Infatuations, interests, research inclinations}

Some years ago two young Estonian folklorists E. H. Västrik and M. Arukask completed a two-part documentary entitled The Two Loves of Paul Ariste. The title, however, is not completely correct: he did not have just two loves, but two great loves, because the lively and curious academician had quite a number of academic infatuations. These two that were addressed in the documentary were Gypsies and Votians. However, in terms of academic legacy these areas of study do not stand comparison.

While the study of Votian language and folklore formed the most extensive and permanent part of Ariste's life's work, the Gypsy language and folklore is rather modestly represented in his bibliography (Onga 2000). Infatuation, of course, is something that cannot be measured by the scope of articles or books. Regardless of the relatively short list of his articles on the Gypsy language and folklore, they still provide an interesting reading experience even decades later. The most important of the materials are folklore accounts and the published collection of folk tales. The professor also took pleasure in impressing Gypsies and others with his skills in speaking the Gypsy (Karma 1986). Interestingly enough, he made his first phonographic recordings of Gypsy lore among the Gypsy, who had been sent to East Estonia and whom 


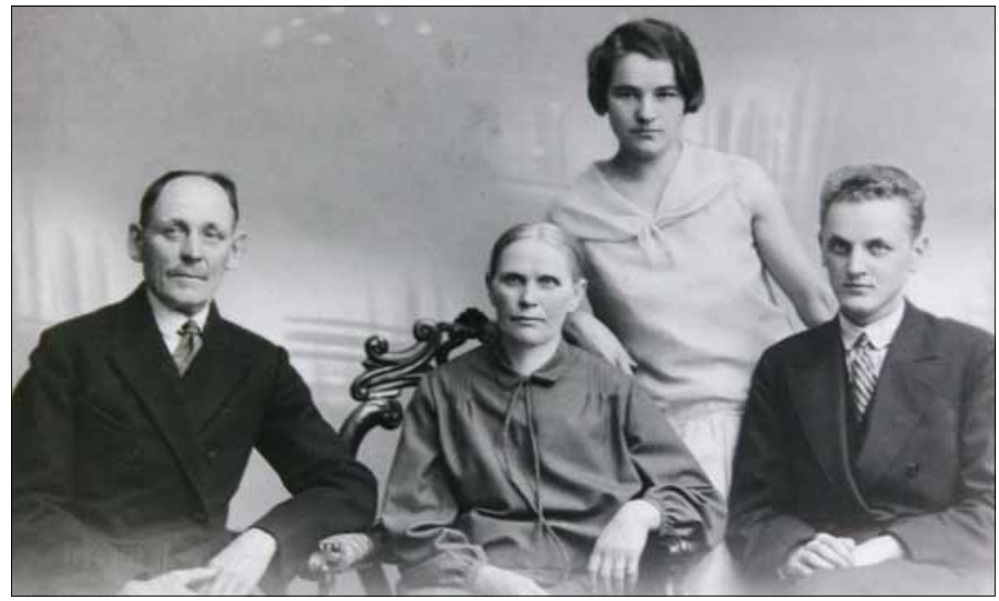

Photo. Family picture from 1928. Father Aleksander Berg (left), mother Liisa Berg, wife Erna Ariste and Paul Ariste. Photograph collection of EFA, B-68: 271.

he met by a coincidence in 1929 , without knowing their language. But already in 1935 the written press published articles on his Gypsy language skills. From the viewpoint of the written press this was a popular topic, attracting the interest of many journalists.

In his numerous reminiscent articles Ariste admits that of all the languages he could speak, he loved Swedish and Yiddish the most, as both, he said, were "succulent". He had acquired the former already in his childhood, from a grandmother whose father had been of Swedish descent, but he had also practiced it with one of his schoolmates, and had learned Yiddish from another schoolmate (Ariste 1988). Later he also improved his skills, and, in addition, learned Hebrew. Of these interests, one appears to have been more productive - his studies into the Swedish language resulted, among other things, in an MA thesis, and his contribution to the comprehensive bilingual Swedish-Estonian dictionary, numerous articles on language and folklore, and recording of Swedish folklore. The role of Yiddish (and Hebrew) in his life somewhat resembles his interest in the Gypsy language, because these languages, too, attracted public interest and Ariste 
enjoyed being mistaken for a Jew based on his language skills. His contribution to the history of Estonian etymology as a longtime collector of Jewish lore and with his articles on Hebraic biblical loans is highly valuable.

His acquisition of the Latvian language, which proved extremely useful for a scholar of Balto-Finnic languages and folklore, was favoured also by the fact that Erna Ariste, Paul Ariste's wife and ethnographer was a native Latvian. Later Ariste also supervised Latvian post-graduate students, was an opponent to several theses by Latvian scholars, and published in the Estonian press reviews of studies by Latvian scholars, which may have been of interest from the Balto-Finnic viewpoint. Thereby he also contributed immensely to integration. One of his former supervised students, Professor Marta Rudzite turned into a remarkable scholar of language contacts in the Balto-Finnic and Baltic area. Marta Rudzite is married to Tõnu Karma, an Estonian, who has promoted the Estonian and Livonian cause over several decades.

It is hardly possible to measure the extent of interest or infatuation in something, as there are simply no appropriate criteria for that. Also, it is possible that among the many interests of Paul Ariste, the Veps are not even listed among the twelve most important objects of interest and topics of study. So the question is whether anyone would be able to arrange them in a proper, unquestionable order of priority? In recent years the authors of reference articles about Ariste have prioritised his study topics somewhat differently. Kristiina Ross, for example, has listed these accordingly: "The Estonian language and other Balto-Finnic languages, especially Votian, their phonetics and language contacts with other languages, folklore, and Swedish language", but also mentions Jewish and Gypsy language and culture (Ross 2000). Mati Hint has pointed out the general Finno-Ugric studies and general linguistics, experimental phonetics, and Estonian phonetics in particular, but also the study of Low German and Swedish loans in the Estonian language, etc., laying emphasis on his particular interest in the Votian language and folklore (Hint 2000). In his preface to Ariste's biographic bibliography Paul Alvre lists among his main research areas "the Estonian language, BaltoFinnic languages (especially Votian), phonetics, the Swedish lan- 
guage, language contacts and folklore (Alvre 2000). Without being bound with the strict objectivity requirements of reference books, I would like to particularly emphasise P. Ariste's infatuation with peripheral and rare language and cultural phenomena, such as the substrata in the Estonian language that cannot be traced back to any known languages, linguistic enclaves, idiosyncratic words and expressions, often borrowed from foreign languages, which are used when talking to children and animals, and, certainly, Estonian (and Balto-Finnic) etymologies, many of which are connected with folkloric and religious terminology. However, the Veps folklore or language does not stand out among Ariste's more important areas of study.

But even a side interest of a talented and enthusiastic scholar, which Ariste definitely was, may prove surprisingly productive. This has enabled me to freely write about this topic, but I could have also written on his role in the development of Mari linguistics, in the study of the Komi and Izhorian language and Livonian folklore, etc.

Ariste's very first publication was his article La Livoj (Onga 2000, 40(1)), which was published in 1921. This article, which aimed to introduce a tiny Balto-Finnic ethnic group, the Livonians, to the rest of the world and was written in an artificial language for international use by a secondary school student, is almost symbolic. Endeavours towards cross-cultural understanding were therefore interrelated with ideals of kinship; the global became interrelated with the local. Paul Ariste's bibliography shows that he used Esperanto in his writing even during his first years of university, and even though he neglected it later when he turned to more serious academic work, Ariste never really forgot his youth interest. In the Soviet period Esperanto was, in a sense, also a form of resistance, for its use was banned in the Stalinist years and was even later rigorously monitored. Regardless of that Ariste started popularising Esperanto as soon as circumstances became favourable. His practical use of Esperanto later evolved into a theoretical observation of artificial languages (Linnamägi 1996).

Although he mastered a number of living, extinct and artificial languages, Ariste never found it difficult to answer which lan- 
guage he considered most beautiful. He was thoroughly convinced that the most beautiful language was one's mother tongue and managed to spread this conviction among his students and postgraduate students, among the Estonians and people of other, though mostly Finno-Ugric nationality.

It is a common knowledge that Paul Ariste started his academic career in the newly founded Estonian Folklore Archives, working there during 1927-1931. Directly after entering the university he had already chosen the area of his future master's thesis - this was to be on linguistics. But he took his first, somewhat inexperienced steps in academic work as a collector of folklore, recording Votian and Ingrian-Finnish folklore as a secondary school student. His interest in folklore guided him during his whole life. He was good at finding topics which related language and folklore. For instance, he has written about folk tales about languages - an Estonian cheats a Russian estate owner by teaching his children the Estonian language, claiming it to be some nobler language, like Latin, German, etc.; the Estonian language comes second when the beauty of all the world's languages are compared, etc. (Ariste 1963). This topic alone indicates Ariste's double identity in research, which he himself liked to stress - he was both a linguist and a scholar (Ariste 1970).

Perhaps even his interest in folklore was inherited. Paul Ariste, like literati of his generation in general, was born and grew up in the countryside. His birth home was in Northern Tartu County, which was rich in folk tales. Folk tales were also narrated at his home, and family members and relatives also transmitted religious lore.

Ariste's first collection expeditions took him to his home region, the East Estonia, during which he visited and interviewed also his relatives. Quite characteristic is a comment in his 1929 collection diary that he may be one of the "descendants of Votians and poluverniks (the Lutheran Russian community of the Iisak parish in North-East Estonia, who identified themselves with the Estonians already in the $19^{\text {th }}$ century, even though in the 1920s-1930s the older generation still spoke Russian)" (Salve 1988). This was his first addressing the issue of Votians, of whom he had met only a few by then. His statement, though said with a 
tongue in cheek, suggests P. Ariste's receptiveness, his interest in and congeniality to all cultures, which was not carried by ideals, like it is often the case with those who get carried away by the romantic kinship ideas, but was down-to-earth. This becomes particularly evident in his article on the Votian literati D. Tsvetkov, where he not only refutes the accusations to Tsvetkov by other kinship ideologists, but presents solid arguments about the general situation (Ariste 1936a).

Ariste's serious interest in different languages and cultures must have been the impetus, which drove him to focus more on recording the lore of non-Estonians in his years in the Estonian Folklore Archives; he also swept along representatives of other nations. His talent in acquiring languages and his natural communication skills definitely facilitated his work. On Ariste's initiative, though not without the consent of the first head of the folklore archives, Oskar Loorits, separate files were established for the folklore of ethnic minorities then living in Estonia and for the folklore of other, Balto-Finnic peoples in particular (Salve 2000).

\section{Paul Ariste as a collector and publisher of Veps folklore}

The non-Estonian files of the Estonian Folklore Archives (including, e.g. the Russian, German, Jewish, Gypsy, Latvian materials) includes a separate catalogue ERA, Mitmesugused rahvad (Miscellaneous peoples). This small catalogue contains the lore of a surprisingly wide array of nationalities - British, Italians, Chinese, Chukchee, French, Yakuts, Armenians, Americans, as well as various Finno-Ugric nations, like the Veps.

A remarkable part of those included in this versatile list is represented by a single text, which is further categorised under a specific subject. The reason is that once Paul Ariste was asked to collect the tooth spells from as many different peoples as possible. And he did, with great enthusiasm. His work resulted in the first recorded texts on the Veps folklore - three short spells recited on loosing deciduous teeth, which are preserved in the catalogue ERA Mitmesugused rahvad, pages 131-132. 
In this light two almost opposite tendencies in Ariste's scholarly work are revealed: on the one hand he had many interests, he often got carried away and sometimes failed to finish some works because new ones overshadowed the old ones. On the other hand his work was remarkably stable, as he recorded the folklore of different nations for decades in all possible places and situations, for which he had no actual need or obligation after his leaving the Estonian Folklore Archives. His continuous interest compelled him to make interviews about the simple children's spells on his first major academic event after the war and the following brief imprisonment.

Ariste's comments to the recorded texts reveal that the interviews with informants about the Veps culture were conducted during the Conference of Finno-Ugric Studies held from January 23 to February 4 in St. Petersburg (then Leningrad). Even though his informants were all scholars of the Veps language and culture, one of them even a native Veps, the tooth spells are so peripheral and marginal folkloric phenomena (a magic spell on the one hand and a children's lore on the other) that the scholars may never have thought of recording these themselves had they not found themselves in the role of informants.

Thus on January 27, 1947 Paul Ariste wrote down the spells from N. I. Bogdanov, the older generation scholar of Veps nationality, who was born in the village of Simjärv. Another scholar of the Veps studies, M. M. Hämäläinen, a philologist of Ingrian-Finnish descent, was interviewed the next day, on January 28. Hämäläinen had also heard the tooth spells in the Simjärv village, but his differed widely from those written down from Bogdanov. The latter bore more resemblance to the spells of the Northern (Onega) Veps, which Ariste has recorded from a Veps student V. Yegorova from Seltozero a day later. The same sheet of paper also contains an Udmurt text written down by Ariste. Another sheet contains a variety of tooth spells from very many peoples: these texts are also collected during the same conference and were written down, presumably on the request of Ariste, by a Komi-Permyak student Antonina Krivoseinova in the dormitory of the Leningrad University. 
Some years later Ariste recorded the Veps folklore in even larger scope, when he supervised the collection expeditions of the students of the University of Tartu in the villages of mid-Veps dialectal area at the Ojat' river (former Vinnicy raion, which is now Podporozye raion). These expeditions were held on three consecutive years: 1953, 1954, and 1955. The fourth expedition for collecting Veps language material took place a few years later, in 1961, in the then Seltozero raion in the Onega Veps dialectal area. The material collected on these expeditions were later handed over and incorporated into the files of the then Chair of Finno-Ugric languages of the University of Tartu. According to the file register Paul Ariste has handed over more than 400 pages of collected, mainly folkloric material, whereas some of it was already systematised. Unfortunately these valuable collections were a thing of the past, as the materials, like many other manuscript files of the Chair of Finno-Ugric languages, were destroyed in the 1965 fire in the main building of the University of Tartu. In hindsight I am quite sure that had professor Ariste kept the Veps materials at home, where he stored his voluminous Votian files, the Veps materials would still be available for scholars today.

Presently, it is rather difficult to say why Ariste did hand over a relatively small part of his manuscripts to the Estonian Literary Museum. These materials are now held in archival documents RKM, Soome-ugri 2, pp. 625-644, containing mostly songs from the central Veps area, but also one folk tale. According to the register preserved in the University, the destroyed files also included predominantly folkloric material, so the type could not have been the factor. Perhaps the material he gave to the literary museum was intended for publication.

30 typewritten pages in the archival document $R K M$, Soomeugri 2 deserve separate analysis, as they constitute in fact a draft manuscript of the publication that I will discuss in the following.

Namely, Paul Ariste did publish some Veps folk tales he collected (Ariste 1964). The referred publication is the only one which is purely based on Veps material. Another publication which was published decades earlier was an overview of new Balto-Finnic 
literary languages established in the Soviet Union, including the Veps on which Ariste had dedicated about one page (Ariste 1936a).

In this book Ariste describes ways of enriching the vocabulary of the newly established Veps literary language, such as Russian loans, Finnish examples in constructing new derivatives in the languages, description of alphabet, among others the special characters added to the Latin alphabet, etc. Ariste illustrates the Veps literary language with the poem Keväz' ('Spring'), with added translation, from the verse book by F. Andreyev.

The anthology of Veps folktales (Vepsa muinasjutte, Ariste 1964), compiled by Ariste, is very representative of his unique scholarly achievement. His extensive bibliography contains a number of short articles and published materials. The collection of Veps folk tales is also very short, containing only six tales (AT 555II, AT 707, AT 480 AT Andrejev 480*, AT 810 + 530, AT1690* + 1653 B) with translation into Estonian and an extremely laconic summary in Russian, covering not more than a quarter of a page. The anthology is particularly practical because each tale is assigned an AT type number. Another forte of the book was its characteristically laconic preface, which proved highly educational and influential, some even argued that it conveyed some hidden message for the Estonian audience back then, and especially for the younger generation.

Paul Ariste was, no doubt, a natural born teacher, and this feature is evident in the preface under discussion. Considering the publishing situation back then, the preface was supposedly written around 1963 or even earlier, but reflected the experience acquired on the expeditions conducted by the University of Tartu even ten years prior, in the 1950s. The terse characterisation of the preface on the various genres of the Veps folklore and their state at the time has proved somewhat questionable. For example, half a century later I would like to argue that the unrecorded laments were the genre that was most significant in transmitting values in the Veps society.

The younger generation definitely found inspiration in Ariste's claim as if there was "great interest in the Veps folk tales" in the whole wide world; he certainly intended it as inspirational. He 
backs this claim up with articles by I. Levin and W. Anderson, published in Fabula, journal of folk tale studies, in 1961 and 1962. Ariste also points out the bibliographic references of these two articles, which were basically typological analyses of published Veps folk tales. Added to the names of both authors were their then places of residence: the former lived in Leningrad at that time, the latter in Kiel. The older generation of Estonian scholars of the humanities probably remembered that during 1920$1939 \mathrm{~W}$. Anderson was the folklore professor in the University of Tartu; some perhaps even knew of I. Levin's studies in the University of Tartu. The isolation of the period made it even impossible to point out the fact that Estonia brought the two scholars together, but I suppose that the written word served its purpose by reminding the readers who knew, namely, the literati of the older generation, that they would tell about it to those who did not know - the youth.

The most important thing, however, is that Paul Ariste's call to pay more attention to the Veps folklore served its purpose.

Now, let us take a closer look at the narrators of these published folk tales. The first tale of the collection is, unexpectedly, not recorded in the area around the Ojat' river or Lake Onega, but was written down on April 24, 1952 in Tartu by Aleksandra Gorshkova from Seltozero. Unfortunately, we have no information as to how the collector and informant met: we may speculate on various possibilities, but it may very well have been a pure coincidence. In relation with A. Gorshkova I would like to briefly touch upon the issue of the Veps, who have lived and are still living in Estonia, and have arrived here at different times and through different routes. According to the last Soviet census conducted in 1989, the Estonian population included 37 Veps residing in Estonia, of who only 7 spoke Veps as their native language. Stories heard in many Veps villages about their children, relatives or fellow villagers, who have settled in Estonia, suggest that the actual number was (and still is) several times larger. Probably, most Veps have registered themselves as Russians, because according to the former Soviet Union passports the majority of youth who had settled in Estonia since the 1960s were Russians, and people seem to have considered the passport en- 
try authoritative and binding. The 1960s was the period when the youth started to emigrate from the Veps villages. Before this period the settling of a Veps in Estonia was quite rare - the then migrants were either wives of military officials or those who married to Estonian young men. Later mass migration brought young men into various industrial enterprises in North Estonia, whereas young women settled in textile industries in Narova the areas, where the officially favoured immigration had led to the predominance of the Russian-speaking population. Most of the young Veps entered into marriages with Russians and never learned the Estonian language. To my knowledge, one of the few exceptions here are a married couple from Eastern Veps Kuja), who lived in Viljandi, where there was no strong Russian community in the Soviet period, and a woman from South Veps, whose marriage with an Estonian had ended, but whose children and grandchildren were Estonians and spoke Estonian. I have also heard of a few other marriages between the Veps and the Estonians. Five following tales have been recorded in summer 1955 from Anatoli Pantshukov, who was then 14 years old and had moved (probably with his family) from Yaroslavich to Vinnicy some years prior to this. Four tales originate in his home village, but he had heard one from a fishing mate when already living in Vinnicy. At the remarkably young age he was already a brilliant tradition transmitter. My experience from the fieldwork in the 1980s-1990s also confirms that towards the end of the 1940s and the beginning of the $1950 \mathrm{~s}$, folk tales were an important form of entertainment among the (midland) Veps, and among the southern Veps this probably lasted until the 1960s. My own experience has shown that even at the end of the 1970s and the beginning of the 1980s there were some grandmothers who sang and told stories to their grandchildren in the Veps language. An altogether different issue is that now, on the break of the third millennium, the war-time and post-war generation no longer pass on storytelling tradition, even though they often reflect on former brilliant story-tellers and listening to their stories in childhood. Changes in the language and cultural situation, however, have eliminated the opportunity to hear to the lore once told by their grandmothers in the performance of other story-tellers, thus making it impossible for them to construct their personal mental text, and, most importantly, pass on their mother tongue. It 
seems paradoxical that the Veps language communication between different generations was virtually lost after the public discourse on the repudiated Veps people, language and its future was started, after courses in Veps language started, or books and newspapers were published in the language. Older grandparents still often talk Veps with their children, but no longer with their grandchildren. Of course, there might be exceptions to the rule, because Anatoli Pantshukov should now be around 60 , and may still be living somewhere and might remember some of his childhood folk tales.

\section{Teacher and supervisor}

Paul Ariste was not merely a scholar who among other things also wrote popular articles on his area of study. His greatest contribution to the Veps folklore and studies in general, was his productive training of new scholars. By the way, the same applies to his role in the study of most Finno-Ugric languages and cultures. Over several decades Ariste was first and foremost a professor, a mentor, a supervisor. His charismatic personality largely contributed to making the specialty of Finno-Ugric languages the most prestigious and desired area of study for the entire generations of students of the Estonian language. Supervisors may have changed, but Paul Ariste's person played a decisive role. Quite illustrative of his influence are photographs from the university café where students of the Finno-Ugric studies were sitting together for a seminar with P. Ariste and P. Palmeos. Considering the period, of course, the popularity of Finno-Ugric studies could be explained by the fact that this area of study required less compliance with the ideology of the time, which was inevitable in history or literature.

As previously mentioned, Paul Ariste himself supervised student collection expeditions to the villages of mid-Veps dialectal area at the Ojat' river. Fortunately, some materials from these student expedition trips (namely those by Tiiu Mälksoo, Luule Kastein, Ada Ambus, who later studied mainly Votians, and TiitRein Viitso, of the leading Finno-Ugric scholars today) did make their way to the Estonian Folklore Archives. Tiit-Rein Viitso focused on the Veps problems later in his academic career, when 
he collected materials for his $\mathrm{PhD}$ thesis in Northern Onega Veps area. His audio tape recordings from the early 1960s are the very first audio recordings of Veps folklore in the Estonian Folklore Archives. Paul Ariste supervised his PhD thesis on phonology. His thorough knowledge of the Veps language enabled Viitso to contribute immensely to the academic publication of the Veps proverbs (Vepsa vanasõnad).

The materials which cover about 120 pages were recorded by three female students on field expeditions among the Veps, who live at the Ojat' river. These materials contain mostly folk tales and folksongs, but also information about folk religion, etc. It is remarkable that the students have mainly interviewed young women and men around their own age, 20 years, but also younger people. One of the informants was the same Anatoli Pantshukov, whose tales were published by Ariste. This fact is also very illustrative of the native language skills and knowledge of tradition among the contemporary Veps youth.

P. Ariste also supervised BA theses on Veps language by Paul Kokla, the later well-known scholar of Finno-Ugric studies, who moved on to writing his $\mathrm{PhD}$ thesis in the Mari language, as well as by Andres Ehin, who never became a Finno-Ugric scholar, but is a freelance poet and translator.

While Ariste personally led the first expeditions to various FinnoUgric peoples (the Veps, Livonians, Izhorians, Karelians in Valdai), later, when he had already trained a new generation of scholars to replace those who had left to the west during the World War II, they also took over the leading of expeditions. Paula Palmeous, Ariste's student from the pre-war period moved on to studying the Karelian migration routes, but also led student expeditions in the Veps area. Since the late 1960s these expeditions were made to the South-Veps dialectal area, resulting mostly in folkloric and folk religious materials which are now held at the University of Tartu. The main purpose of the students' collection work was to collect linguistic material, but in order to determine the vocabulary of particular topics, the collectors had to write down texts, which inevitably included folkloric material: proverbs, spells, memorates, etc. 
More recent student expeditions also led to a number of studies. Some talented young scholars also turned from linguistic material to other areas of spiritual culture. A good example of such scholars is Marje Joalaid, who has studied proverbs, laments, ritual culture, and owing to her linguistic background, also toponymics. She has put together a preliminary statistics on the Veps material held in the research institutions of Estonia (Joalaid 1982; Joalaid 1979).

Largely owing to Marje Joalaid, along with her, I went to explore the Veps paths. Paul Ariste's life work is indirectly reflected even in the fact that of all the Finno-Ugric peoples, the Veps files are the most extensive in the Estonian Folklore Archives. I can also say from my own experience that Ariste's influence was often very direct, since when still in elementary school I remember reading a popular newspaper article by Ariste, which inspired me to study Finno-Ugric languages. And even though I changed my mind several times, and ended up studying folklore at the university, the Finno-Ugric (or at least Balto-Finnic) languages were still a part of this. To express my gratitude and respect to Paul Ariste I entitled one of my articles on experience from field expeditions to the Veps, on Veps folklore and the leading tradition transmitters (Salve 1997) with a paraphrase of a title of Ariste's article on Votian folklore (Ariste 1970).

Vepsia suddenly became very popular among the Estonian scholars of the humanities. Fieldwork was conducted there by linguists, students of Finno-Ugric studies, as well as by ethnographers under the lead of A. Peterson, anthropologists and even archaeologists. Also grew the number of folklorists (e.g. P. Kippar, V. Mälk, I. Rüütel) and representatives of other fields, who visited the Veps at least once.

I am positive that the Veps experience was enjoyed even by those students who never became linguists or folklorists. Anna Zigure, for example, who has translated from Estonian and Finnish into the Latvian languages, and was in diplomatic service after Latvian regained its independence. I dare to believe that her later experience has not made her forget how a Veps folk healer "set her belly button" (Joalaid, Leivo 1972). 
The largest project on Veps folklore in Estonia, which resulted in the academic publication of the Veps proverbs, cannot, however, be attributed to Paul Ariste, his students, and the students of his students, but was the by-product of the common Balto-Finnic Proverb Project (Krikmann, Sarv 1996), initiated by Finnish folklorist Matti Kuusi. Still, there were several Ariste's students among its editors and it contained material collected by them.

Certainly, in the light of what has been said above, we must bear in mind that regardless of the period of excitement, Estonia has never been the only or the most important centre of studying and collecting material on Veps culture and language. One of the most important centres has undoubtedly been the one in the Republic of Karelia. Paul Ariste, however, has indirectly contributed even to the work of this centre, because he supervised M. Zaitseva, a productive collector and publisher from the folkloristic viewpoint. The academician also edited and reviewed a number of monumental publications, which contained valuable folkloric materials, by scholars of Petrozavodsk. This, of course, is of marginal importance in this article. We should also not forget the long interest of Finnish scholars in the Veps cause, which started already in the $19^{\text {th }}$ century and in the post-war period covered mostly the publication of the earlier material, but which regained its popularity in the period following the isolation of the Soviet regime, though this, again, nearly remains outside of the topic of this article. Nearly, because Paul Ariste took interest in all this as well.

\section{Reference:}

Alvre, Paul 2000. Paul Ariste - viljakas soome-ugri keelte uurija. Onga, Mare (koost). Professor Paul Ariste biobibliograafia 1921-2000 = Professor Paul Ariste: Biobibliographie 1921-2000. Tartu: Tartu Ülikooli Raamatukogu, lk 12-24.

Ariste, Paul 1936a. Uusi läänemere-soome kirjakeeli [vepsa, tverikarjala, ingeri]. Eesti Kirjandus 5, lk 228-229.

Ariste, Paul 1936b. Dimitri Tsvetkov: Ühest vadja haritlasest. Eesti Kirjandus 8, lk 370-373.

Ariste, Paul 1963. "Kogemata eesti keel”. Keel ja Kirjandus 5, lk 274-275.

Ariste, Paul 1964. Vepsa muinasjutte (Äänis- ja keskvepsa keelenäiteid). 
Palusalu-Adler, Elna (toim). Töid Läänemeresoome ja Volga keelte alalt. Tallinn: Eesti NSV Teaduste Akadeemia Keele ja Kirjanduse Instituut, lk $5-23$.

Ariste, Paul 1970. Vadja rahvaluule võlus. Valmet, Aino et al. (koost). Saaremaast Sajaanideni ja kaugemalegi: Kogumik. Tallinn:Valgus, lk 89-99.

Ariste, Paul 1988. Koolmeistergi võib kasvatada lingvisti. Ahven, Heino (toim). Kodumurre 19. Tallinn: Eesti NSV Teaduste Akadeemia Emakeele Selts, lk 6-11.

Hint, Mati 2000. Ariste, Paul. Kruus, Oskar \& Puhvel, Heino (koost). Eesti kirjanike leksikon. Tallinn: Eesti Raamat, lk 41-42.

Joalaid, Marje 1982. Vepsa rahvaluule kogumisest Eestis. Linnus, Jüri (koost ja toim). Läänemeresoomlaste etnokultuuri küsimusi: Etnograafiamuuseumi teaduspäevade ettekannete kogumik. Tallinn: Valgus, lk 8-12.

Joalaid, Marje \& Leivo, Maeve 1972. Esimest korda vepslaste juures: 1968. Ahven, Heino (toim). Kodumurre 10-11. Tallinn: Eesti NSV Teaduste Akadeemia Emakeele Selts, lk 88-92.

Karma, Tõnu 1986. Vahejuhtum Riia-Vindavi reisirongis. Ahven, Heino et al. (toim). Keelest ja rahvaluulest. Emakeele Seltsi aastaraamat 30 (1984). Tallinn: Eesti Raamat, lk 197-199.

Krikmann, Arvo \& Sarv, Ingrid 1996. The Tartu Research Group of Paremiology. Folklore: An Electronic Journal of Folklore 2, lk 87-115.

Linnamägi Madis 1996. Interlingvist Paul Ariste. Künnap, Ago (toim). Fenno-Ugristica 19. Tartu: Tartu Ülikool, lk 130-136.

Onga, Mare (koost) 2000. Professor Paul Ariste biobibliograafia 19212000 = Professor Paul Ariste: Biobibliographie 1921-2000. Tartu: Tartu Ülikooli Raamatukogu.

Ross, Kristiina 2000. Ariste (a-ni 1927 Berg), Paul. Siilivask, Karl (peatoim). Eesti teaduse biograafiline leksikon 1 (A-Ki). Tallinn: Eesti Entsüklopeediakirjastus, lk 93-94.

Salve, Kristi 1988. Ühe noore rahvaluulekoguja jälgedes. Ahven, Heino (toim). Kodumurre 19, Tallinn: Eesti NSV Teaduste Akadeemia Emakeele Selts, lk 17-25.

Salve, Kristi 1997. Vepsa rahvaluule lummas. Mäetagused 4, lk 65-80.

Salve, Kristi 2002. Muude rahvaste folkloor Eesti Rahvaluule Arhiivis.

Hiiemäe, Mall \& Labi, Kanni (toim). Kogumisest uurimiseni : artikleid Eesti Rahvaluule Arhiivi 75. aastapäevaks. Eesti Rahvaluule Arhiivi toimetused= Commentationes Archivi Traditionum Popularium Estoniae 20. Tartu: Eesti Kirjandusmuuseum, lk 29-52.

VV 1992 = Mälk, Vaina \& Hussar, Anne \& Kährik, Aime \& Viitso, TiitRein (koost). Vepsa vanasõnad: Eesti, vadja, liivi, karjala ja vene vastetega 